\title{
ODDZIAŁYWANIE PROGRAMÓW WSPIERAJACYCH AKTYWIZACJĘ OSÓB Z NIEPEŁNOSPRAWNOŚCIĄ NA ZMIANĘ ICH SYTUACJI NA RYNKU PRACY
}

\author{
Żaneta Gadzinowska \\ Politechnika Częstochowska \\ Wydział Zarządzania
}

\begin{abstract}
Streszczenie: Osoby z niepełnosprawnością w Polsce napotykają na liczne utrudnienia i bariery - począwszy od niedostosowanych placówek szkolnych, a kończąc na problemach związanych ze znalezieniem pracy. $Z$ tego powodu są szczególnie narażone na wykluczenie społeczne. Wdrażanie programów aktywizacji pomaga w likwidowaniu ograniczeń związanych z udziałem osób z niepełnosprawnością w życiu społecznym. Realizacja działań w ich ramach wspiera zarówno inwestycje przystosowujące infrastrukturę, jak również przedsięwzięcia służące poprawie jakości wykształcenia i kompetencji ww. osób oraz ułatwiające start i rozwój zawodowy.
\end{abstract}

Słowa kluczowe: niepełnosprawność, osoba z niepełnosprawnością, aktywizacja, rynek pracy

DOI: 10.17512/znpcz.2016.2.12

\section{Wprowadzenie}

Celem artykułu jest analiza oddziaływania wdrażanych programów wspierających aktywizację osób z niepełnosprawnością na zmianę sytuacji społeczno-zawodowej osób $\mathrm{z}$ orzeczonym stopniem niepełnosprawności. Aktywizacja zawodowa osób z niepełnosprawnością jest ważnym zagadnieniem w polityce społecznej i stanowi istotne wyzwanie dla polityki społecznej w naszym kraju. Sytuacja na rynku pracy osób bezrobotnych z niepełnosprawnością jest trudna ze względu na niewielką liczbę etatów przeznaczonych dla takich osób, bowiem wiąże się to niejednokrotnie z potrzebą stworzenia im szczególnych warunków pracy, wymagających dodatkowych nakładów finansowych. Poziom zatrudnienia w Polsce należy do najniższych w Europie. Jednocześnie odsetek osób z niepełnosprawnością w populacji jest stosunkowo wysoki w porównaniu z sytuacją w innych krajach Unii Europejskiej. Wskaźnik zatrudnienia osób z niepełnosprawnością różni się o $26 \%$ od średniego wskaźnika zatrudnienia w UE, przy czym wskaźnik zatrudnienia osób niepełnosprawnych wynosi mniej niż 50\% (http://www.europarl.europa.eu/sides/getDoc. do?pubRef=-//EP//TEXT+REPORT+A8-2015-0222+0+DOC+XML+V0//PL).

Zarówno teoretycy, jak i praktycy są zgodni, że osoby z niepełnosprawnością powinny być zdecydowanie bardziej aktywne na rynku pracy. Zbiór działań prowadzących do zwiększenia udziału tych osób w rynku pracy jest bardzo szeroki i obejmuje między innymi modyfikację istniejących przepisów prawa, realizację 
wielu rozmaitych programów, które w swoim założeniu powinny zmienić sytuację osób bezrobotnych z orzeczoną niepełnosprawnością. Nowe szanse stwarza również dostępność środków Europejskiego Funduszu Społecznego, którego głównym celem w Polsce jest zwiększenie poziomu zatrudnienia i ograniczenie wykluczenia społecznego.

Obecnie w Polsce zatrudnienie osób z niepełnosprawnością jest niewielkie i wynosi 243755 osób (http://www.niepelnosprawni.gov.pl/p,83,sodir-pfron); wynika to ze strachu, uprzedzeń oraz niewiedzy na temat schorzeń tych osób. Na osoby $\mathrm{z}$ orzeczonym stopniem niepełnosprawności niejeden $\mathrm{z}$ pracodawców patrzy przez pryzmat kłopotów i kosztów związanych $\mathrm{z}$ podjęciem przez nie pracy na określonym stanowisku. Niestety, niektórzy pracodawcy, widząc osobę na wózku czy z innym widocznym schorzeniem i osobę pełnosprawną, reagują w sposób jednoznaczny, zatrudniając osobę pełnosprawną, nie dając tym samym, żadnych szans na wykazanie się wiedzą czy umiejętnościami osobie mniej sprawnej. W Polsce, aby zachęcić pracodawców do zatrudniania osób z niepełnosprawnością, wprowadzono szereg przywilejów, które mają wspomagać zatrudnienie tych osób. Katalog dostępnych źródeł dofinansowania, przeznaczonych na realizację programów aktywizacji osób z niepełnosprawnością jest bardzo rozbudowany. W celu ich usystematyzowania można podzielić je na dwie grupy:

1) fundusze Unii Europejskiej i środki dostępne w ramach poszczególnych programów operacyjnych;

2) środki z funduszy krajowych, działań celowych i grantów.

Każdy z funduszy, grantów, krajowych czy zagranicznych źródeł dofinansowania precyzuje, jakie działania mogą być w jego ramach finansowane i kto może zostać objęty wsparciem, czyli do jakiej grupy skierowane będą działania zaplanowane $w$ ramach projektu. W gronie tym znaczną grupę stanowią osoby $\mathrm{z}$ niepełnosprawnością, które w nomenklaturze projektowej zwane są beneficjentami ostatecznymi, czyli odbiorcami wsparcia w ramach danego projektu.

Wśród funduszy unijnych, podstawowym narzędziem wsparcia aktywizacji jest Program Operacyjny Kapitał Ludzki (PO KL).

Osoby z niepełnosprawnością są jedną z grup objętych wsparciem Programu Kapitał Ludzki, ze względu na swoją trudną sytuację na rynku pracy. Osoby te mogą korzystać z większości działań zaplanowanych w Programie Kapitał Ludzki. Istnieją zróżnicowania regionalne $\mathrm{w}$ zakresie liczby osób $\mathrm{z}$ niepełnosprawnością, które brały udział w projektach. Największy procent osób z niepełnosprawnością uzyskał wsparcie w województwach: wielkopolskim $(5,43 \%)$, łódzkim $(5,43 \%)$ i lubelskim (4,73\%), a najmniejszy w warmińsko--mazurskim $(2,55 \%)$ i kujawskopomorskim (2,77\%) (Petno spraw dla osób niepetnosprawnych 2011).

\section{Aktywizacja osób z niepelnosprawnością za pomocą programów - diagnoza możliwości wobec potrzeb i wyzwań rynku pracy. Wyniki badań}

W niniejszym punkcie podjęto próbę diagnozy możliwości, jakie stoją przed osobami dotkniętymi niepełnosprawnością w obliczu potrzeb i wyzwań stawianych 
przez rynek pracy. Osoby z niepełnosprawnością napotykają na liczne ograniczenia zewnętrzne $\mathrm{w}$ dostępie do edukacji oraz aktywności zawodowej. Problem ten wynika również z rozmiarów i powszechności jego występowania, a także z konsekwencji, jakie wywołuje w sensie indywidualnym i społecznym. Badania przeprowadzono na grupie 47 osób z umiarkowanym stopniem niepełnosprawności (w tym 32 kobiet i 15 mężczyzn).

Tabela 1. Wiek i płeć badanych

\begin{tabular}{|c|c|c|c|c|c|c|c|}
\hline \multirow{2}{*}{ Lp. } & \multirow{2}{*}{ Wiek } & \multicolumn{2}{|c|}{ Kobiety } & \multicolumn{2}{c|}{ Mężczyźni } & \multicolumn{2}{c|}{ Razem } \\
\cline { 2 - 8 } & 18-25 lat & 3 & 9,4 & 1 & 6,7 & 4 & 8,5 \\
\hline 1 & $26-35$ lat & 14 & 43,8 & 8 & 53,3 & 22 & 46,8 \\
\hline 2 & $36-50$ lat & 13 & 40,6 & 4 & 26,7 & 17 & 36,2 \\
\hline 3 & pow. 50 lat & 2 & 6,2 & 2 & 13,3 & 4 & 8,5 \\
\hline 4 & 32 & 100,0 & 15 & 100,0 & 47 & 100,0 \\
\hline \multicolumn{2}{|c|}{ Ogółem } & 32 &
\end{tabular}

Źródło: Opracowanie własne na podstawie badania ankietowego

Jak wynika z danych zawartych w Tabeli 1 , największą grupę - 22 osoby, czyli $46,8 \%$ - stanowiły osoby z niepełnosprawnością w przedziale wiekowym 26-35 lat, w tym 14 kobiet oraz 8 mężczyzn. Kolejną pod względem liczebności grupą $(36,2 \%)$ byli niepełnosprawni w wieku $36-50$ lat (13 kobiet i 4 mężczyzn). Najmniej liczne grupy stanowiły osoby z niepełnosprawnością w wieku 18-25 lat i powyżej 50 lat (po 4 osoby, czyli 8,5\% ogółu ankietowanych).

Tabela 2. Stopień niepelnosprawności badanych

\begin{tabular}{|c|c|c|c|c|c|c|c|}
\hline \multirow{2}{*}{ Lp. } & \multirow{2}{*}{$\begin{array}{ll}\begin{array}{l}\text { Stopień } \\
\text { niepełnosprawności }\end{array} & \text { Płeć } \\
\end{array}$} & \multicolumn{2}{|c|}{ Kobiety } & \multicolumn{2}{|c|}{ Mężczyźni } & \multicolumn{2}{|c|}{ Razem } \\
\hline & & $\mathrm{L}$ & $\%$ & $\mathrm{~L}$ & $\%$ & $\mathrm{~L}$ & $\%$ \\
\hline 1 & znaczny & 0 & 0 & 0 & 0 & 0 & 0 \\
\hline 2 & umiarkowany & 32 & 100 & 15 & 100 & 47 & 100 \\
\hline 3 & lekki & 0 & 0 & 0 & 0 & 0 & 0 \\
\hline & Ogółem & 32 & 100 & 15 & 100 & 47 & 100 \\
\hline
\end{tabular}

Źródło: Opracowanie własne na podstawie badania ankietowego

Jak wynika $\mathrm{z}$ danych przedstawionych $\mathrm{w}$ Tabeli 2, wszyscy ankietowani (100\%) to osoby z umiarkowanym stopniem niepełnosprawności.

$\mathrm{Z}$ danych przedstawionych w Tabeli 3 wynika, że jako główną przeszkodę w zatrudnianiu osób dotkniętych niepełnosprawnością w naszym kraju respondenci podają niechęć pracodawców do zatrudniania niepełnosprawnych. Taką opinię wyraziło $83 \%$ badanych, w tym 30 kobiet $(93,6 \%)$ oraz 9 mężczyzn $(60 \%)$.

Następnym mankamentem, jaki dostrzega ponad trzy czwarte ankietowanych (78,7\% - w tym 25 kobiet, tj. 78,1\% oraz 12 mężczyzn, tj. 80\%), jest biurokracja przy wypełnianiu dokumentacji związanej z dofinansowaniem z PFRON. Ankietowani krytycznie odnieśli się także do braku informacji na temat osób $\mathrm{z}$ orzecze- 
niem o stopniu niepełnosprawności i ich możliwości zawodowych. Takiego zdania było $44,7 \%$ badanych, tj. 15 kobiet $(46,9 \%)$ oraz 6 mężczyzn $(60 \%)$.

Znaczna część badanych $(40,4 \%)$ twierdzi, że osoby z niepełnosprawnością nie mają odpowiedniego dostępu do rynku pracy; taką opinię wyraziło 10 kobiet $(31,3 \%)$ i 9 mężczyzn (60\%). Niemal co piąta badana osoba $(19,1 \%)$ narzeka na trudności komunikacyjne związane z dojazdem do pracy, natomiast 17\% ogółu respondentów wskazuje na niedostatki w uregulowaniach prawnych dotyczących osób z orzeczeniem o stopniu niepełnosprawności. Co dziesiąty badany $(10,6 \%)$ za jedną z przyczyn utrudniających zatrudnianie osób z niepełnosprawnością uważa konieczność odpowiedniego wyposażenia/przystosowania miejsc pracy przeznaczonych dla osób z dysfunkcjami. Ponadto 3 kobiety (6,4\% ogółu respondentów) upatrują przyczyn takiego stanu rzeczy w braku skoordynowanej współpracy pomiędzy instytucjami działającymi na rzecz osób z niepełnosprawnością.

Tabela 3. Główne przeszkody w zatrudnianiu osób niepełnosprawnych w Polsce - w opinii badanych

\begin{tabular}{|c|c|c|c|c|c|c|c|}
\hline \multirow{2}{*}{ Lp. Płeć } & \multicolumn{2}{|c|}{ Kobiety } & \multicolumn{2}{c|}{ Mężczyźni } & \multicolumn{2}{c|}{ Razem } \\
\cline { 2 - 7 } & Odpowiedzi & $\mathrm{L}$ & $\%$ & $\mathrm{~L}$ & $\%$ & $\mathrm{~L}$ & $\%$ \\
\hline 1 & $\begin{array}{c}\text { niechęć pracodawców do niepełno- } \\
\text { sprawnych }\end{array}$ & 30 & 93,6 & 9 & 60,0 & 39 & 83,0 \\
\hline 2 & $\begin{array}{c}\text { biurokracja przy wypełnianiu dokumen- } \\
\text { tacjizwiązanej z dofinansowaniem } \\
\text { z PFRON }\end{array}$ & 25 & 78,1 & 12 & 80,0 & 37 & 78,7 \\
\hline 3 & $\begin{array}{c}\text { brak informacji na temat osób } \\
\text { z niepełnosprawnością i ich możliwości } \\
\text { zawodowych }\end{array}$ & 15 & 46,9 & 6 & 40,0 & 21 & 44,7 \\
\hline 4 & niewłaściwe prawodawstwo & 6 & 18,8 & 2 & 13,3 & 8 & 17,0 \\
\hline 5 & $\begin{array}{c}\text { brak współpracy pomiędzy instytucjami } \\
\text { działającymi na rzecz niepełnospraw- } \\
\text { nych }\end{array}$ & 3 & 9,4 & 0 & 0,0 & 3 & 6,4 \\
\hline 6 & $\begin{array}{c}\text { brak dostępu do rynku pracy dla osób } \\
\text { z niepełnosprawnością }\end{array}$ & 10 & 31,3 & 9 & 60,0 & 19 & 40,4 \\
\hline 7 & $\begin{array}{c}\text { niechęć osób z niepełnosprawnością do } \\
\text { podejmowania pracy }\end{array}$ & 0 & 0,0 & 0 & 0,0 & 0 & 0,0 \\
\hline 8 & $\begin{array}{c}\text { trudności komunikacyjne (dojazd do } \\
\text { pracy) }\end{array}$ & 5 & 15,6 & 4 & 26,7 & 9 & 19,1 \\
\hline 9 & $\begin{array}{c}\text { trudności z odpowiednim wyposaże- } \\
\text { niem miejsc pracy }\end{array}$ & 2 & 6,2 & 3 & 20,0 & 5 & 10,6 \\
\hline 10 & inne & 0 & 0,0 & 0 & 0,0 & 0 & 0,0 \\
\hline
\end{tabular}

* Odpowiedzi nie sumują się - badani mieli możliwość wielokrotnego wyboru (maks. 3 odpowiedzi).

Źródło: Opracowanie własne na podstawie badania ankietowego

\section{Konkurencyjność pracy osób z niepełnosprawnością jako składnik działań marketingowych}

Stan aktywności zawodowej osób z dysfunkcjami w dobie kryzysu rynku pracy stwarza pesymistyczny obraz. Co prawda wyniki badań zaprezentowane w niniejszej pracy dotyczą osób $\mathrm{z}$ niepełnosprawnością, które pracowały $\mathrm{w}$ momencie 
prowadzenia badań. Taki brak aktywności skutkuje zazwyczaj ubóstwem i wykluczeniem społecznym, a to z kolei powoduje, że grupa osób z niepełnosprawnością w większości utrzymuje się ze świadczeń rentowych i z pomocy społecznej.

Szansą na zmianę tej niekorzystnej sytuacji są działania aktywizujące, w szczególności za pośrednictwem specjalnych programów skierowanych do tej grupy społecznej.

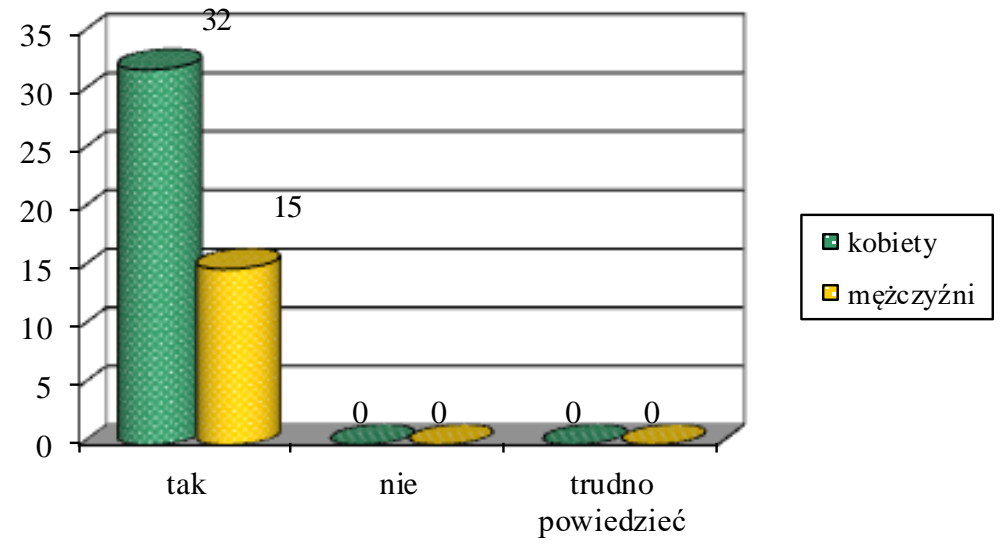

Rysunek 1. Konieczność inicjatyw/działań/programów na rzecz aktywizacji i polepszania sytuacji osób z orzeczeniem o stopniu niepelnosprawności na rynku pracy

Źródło: Opracowanie własne na podstawie badania ankietowego

Jak widać na powyższym diagramie (Rysunek 1), żadna z badanych osób (100\% wskazań: „tak”) nie kwestionuje konieczności podejmowania różnych inicjatyw i działań, a także uruchamiania programów służących aktywizacji i polepszeniu sytuacji osób z niepełnosprawnością na rynku pracy. Wynik taki wobec nie najlepszej sytuacji niepełnosprawnych - nie podlega kwestii, jednakże istotnym problemem jest, kto i w jakim zakresie powinien tę aktywizację wspierać. Opinie badanych na ten temat przedstawiają Tabela 4 i Tabela 5.

Tabela 4. Odpowiedzialność instytucji/organizacji za dzialania na rzecz aktywizacji osób z niepelnosprawnością na rynku pracy - w opinii badanych

\begin{tabular}{|c|c|c|c|c|c|c|c|}
\hline \multirow{2}{*}{ Lp. Płeć } & \multicolumn{2}{c|}{ Kobiety } & \multicolumn{2}{c|}{ Mężczyźni } & \multicolumn{2}{c|}{ Razem } \\
\cline { 3 - 8 } & Instytucje & $\mathrm{L}$ & $\%$ & $\mathrm{~L}$ & $\%$ & $\mathrm{~L}$ & $\%$ \\
\hline 1 & instytucje rządowe & 32 & 100,0 & 12 & 80,0 & 44 & 93,6 \\
\hline 2 & władze lokalne & 29 & 90,6 & 12 & 80,0 & 41 & 87,2 \\
\hline 3 & instytucje rynku pracy & 4 & 12,5 & 8 & 53,3 & 12 & 25,5 \\
\hline 4 & organizacje pozarządowe & 21 & 65,6 & 4 & 26,7 & 25 & 53,2 \\
\hline 5 & żadne (nie ma potrzeby ich istnie- \\
nia) & 0 & 0,0 & 0 & 0,0 & 0 & 0,0 \\
\hline 6 & trudno powiedziećn & 10 & 31,3 & 9 & 60,0 & 19 & 40,4 \\
\hline
\end{tabular}

* Odpowiedzi nie sumują się - badani mieli możliwość wielokrotnego wyboru (3 odpowiedzi).

Źródło: Opracowanie własne na podstawie badania ankietowego 
Jak widać na podstawie wyników badań przedstawionych w Tabeli 4, przeważająca większość badanych $(93,6 \%$, tj. wszystkie kobiety - 32, a także 12 mężczyzn) sądzi, że największe zadania do wykonania w tym zakresie mają instytucje rządowe. Nieco mniejsza grupa (87,2\%, tj. 29 kobiet i 12 mężczyzn) uważa, że odpowiedzialność taka spoczywa także na władzach lokalnych. Ponad połowa respondentów $(53,2 \%$, w tym 21 kobiet i 4 mężczyzn) upatruje w tej materii roli organizacji pozarządowych. Tylko jedna czwarta indagowanych osób z niepełnosprawnością $(25,5 \%$, w tym 4 kobiety i 8 mężczyzn) jest zdania, że stosownych inicjatyw dotyczących aktywizacji mogą oczekiwać od instytucji rynku pracy, czyli podmiotów realizujących zadania na rzecz promocji zatrudnienia i przeciwdziałania bezrobociu.

Niemała grupa, bo 40,4\% respondentów, w tym 10 kobiet i 9 mężczyzn, odpowiadając „trudno powiedzieć”, nie potrafiła dokonać odpowiedniej systematyki i gradacji odpowiedzialności instytucji/organizacji, które zaangażowane są w działania aktywizujące na rzecz osób z niepełnosprawnością. O tym, że instytucje takie są niezbędne, świadczy fakt, iż żadna z badanych osób nie stwierdziła, iż „nie ma potrzeby ich istnienia", natomiast ważną rzeczą jest rola, jaką podmioty te mają do spełnienia.

Tabela 5. Rola instytucji wspierających osoby z niepelnosprawnością - w opinii badanych

\begin{tabular}{|c|c|c|c|c|c|c|c|}
\hline \multirow{2}{*}{ Lp. Płeć } & \multicolumn{2}{|c|}{ Kobiety } & \multicolumn{2}{c|}{ Mężczyźni } & \multicolumn{2}{c|}{ Razem } \\
\cline { 3 - 7 } & Odpowiedzi & $\mathrm{L}$ & $\%$ & $\mathrm{~L}$ & $\%$ & $\mathrm{~L}$ & $\%$ \\
\hline 1 & $\begin{array}{c}\text { wspomaganie edukacji oraz rozwoju } \\
\text { osób z niepełnosprawnością }\end{array}$ & 6 & 18,8 & 2 & 13,3 & 8 & 17,0 \\
\hline 2 & wyrównywanie szans & 4 & 12,5 & 6 & 40,0 & 10 & 21,3 \\
\hline 3 & $\begin{array}{c}\text { aktywizacja społeczno- } \\
\text {-zawodowa osób z niepełnosprawnością }\end{array}$ & 18 & 56,2 & 6 & 40,0 & 24 & 51,1 \\
\hline 4 & $\begin{array}{c}\text { wzrost świadomości społecznej oraz } \\
\text { zainteresowania sytuacją osób } \\
\text { z niepełnosprawnością }\end{array}$ & 4 & 12,5 & 1 & 6,7 & 5 & 10,6 \\
\hline 5 & inne & 0 & 0,0 & 0 & 0,0 & 0 & 0,0 \\
\hline
\end{tabular}

Źródło: Opracowanie własne na podstawie badania ankietowego

Analiza wyników zaprezentowanych w Tabeli 5 pozwala stwierdzić, iż ponad połowa badanych $(51,1 \%)$ oczekuje wsparcia w postaci działań aktywizujących społecznie i zawodowo osoby z niepełnosprawnością. Takiego zdania było 18 kobiet $(56,2 \%)$, a także 6 mężczyzn (40\%). Co piąty badany $(21,3 \%)$ chciałby, aby instytucje wspierające mogły być pomocne przy wyrównywaniu szans ww. osób (4 kobiety i 6 mężczyzn; odpowiednio 12,5\% i 40\% w kategoriach płci). Tylko $17 \%$ (6 kobiet i 2 mężczyzn) upatruje pomocy instytucjonalnej we wspomaganiu edukacji oraz rozwoju osób z niepełnosprawnością. Zaledwie co piąta $\mathrm{z}$ badanych osób (10,6\%, 4 kobiety i 1 mężczyzna) chciałaby, aby instytucje zajmujące się wspieraniem osób z orzeczeniem o stopniu niepełnosprawności w większym stopniu wpływały na wzrost świadomości społecznej. 


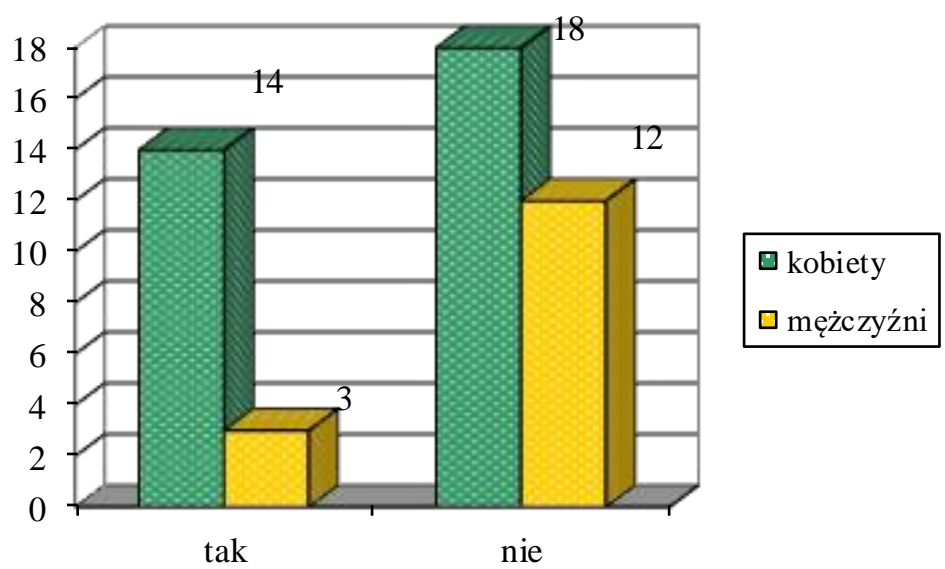

Rysunek 2. Uczestnictwo badanych w programie/projekcie wspierania aktywności zawodowej osób niepelnosprawnych

Źródło: Opracowanie własne na podstawie badania ankietowego

Jak wskazują dane zobrazowane na Rysunku 2, większość badanych $(63,8 \%$ w tym 18 kobiet i 12 mężczyzn) nie uczestniczyła, niestety, w programach, które mają służyć aktywizacji zawodowej osób z niepełnosprawnością, a tym samym zwiększać ich szanse na rynku pracy. Tylko 36,2\% (14 kobiet i 3 mężczyzn) miało - jak dotąd - styczność z tego typu działaniami, a były to przede wszystkim kursy, takie jak np. decoupage, florystyczny, komputerowy.

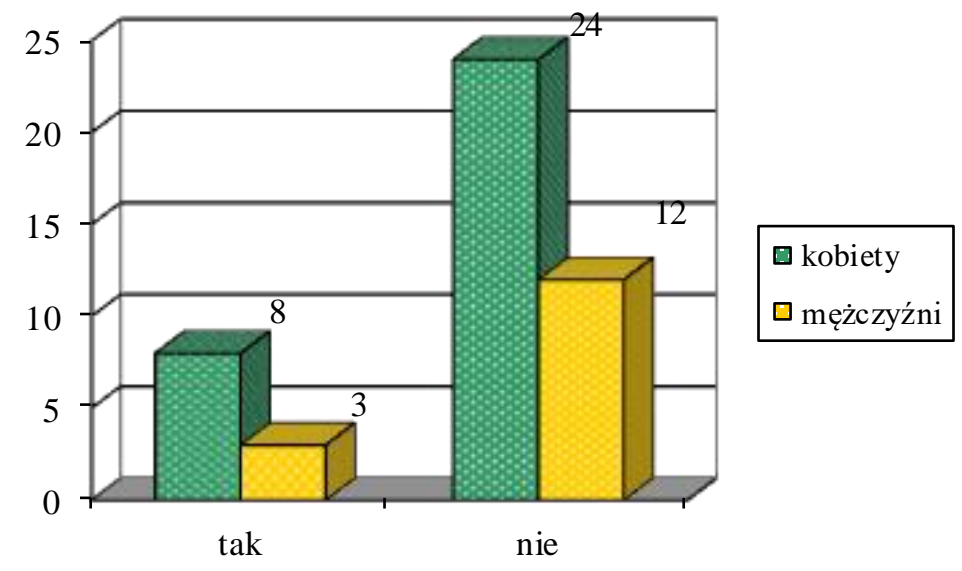

Rysunek 3. Wystarczalność programów aktywizacji zawodowej osób $\mathrm{z}$ niepelnosprawnością - w opinii badanych

Źródło: Opracowanie własne na podstawie badania ankietowego 
Jak wynika z danych graficznych przedstawionych na Rysunku 3, ponad trzy czwarte respondentów $(76,6 \%$, tj. 24 kobiety i 12 mężczyzn) uważa, że oferta programów aktywizujących, kierowanych do osób z niepełnosprawnością, jest niewystarczająca. Można domniemywać, że również informacje w tym względzie nie są odpowiednio „kolportowane” wśród osób z niepełnosprawnością, które poszukują w tych działaniach szansy na zmianę osobistej sytuacji. Pozostałe osoby $(23,4 \%, \mathrm{tj}$. 8 kobiet i 3 mężczyzn) twierdziły, iż zakres i dostępność do programów aktywizujących są wystarczające.

Tabela 6. Gotowość badanych do podnoszenia swoich kwalifikacji

\begin{tabular}{|c|c|c|c|c|c|c|c|}
\hline \multirow{2}{*}{ Lp. } & \multirow{2}{*}{ Płeć } & \multicolumn{2}{|c|}{ Kobiety } & \multicolumn{2}{|c|}{ Mężczyźni } & \multicolumn{2}{c|}{ Razem } \\
\cline { 2 - 8 } & Odpowiedzi & $\mathrm{L}$ & $\%$ & $\mathrm{~L}$ & $\%$ & $\mathrm{~L}$ & $\%$ \\
\hline 1 & przekwalifikowanie na kursie & 6 & 18,8 & 2 & 13,3 & 8 & 17,0 \\
\hline 2 & $\begin{array}{c}\text { przyuczenie do zawodu na stanowisku } \\
\text { pracy }\end{array}$ & 17 & 53,1 & 6 & 40,0 & 23 & 48,9 \\
\hline 3 & podjęcie działalności gospodarczej & 0 & 0,0 & 0 & 0,0 & 0 & 0,0 \\
\hline 4 & brak chęci podnoszenia kwalifikacji & 9 & 28,1 & 7 & 46,7 & 16 & 34,1 \\
\hline & Ogółem & 32 & 100,0 & 15 & 100,0 & 47 & 100,0 \\
\hline
\end{tabular}

Źródło: Opracowanie własne na podstawie badania ankietowego

Bardzo istotne są chęci do podnoszenia własnych kwalifikacji zawodowych przez osoby z niepełnosprawnością. Ma to olbrzymie znaczenie w sytuacji dość dynamicznych zmian na rynku w zakresie potrzeb pracodawców. W Tabeli 6 zaprezentowano wyniki badań tego zagadnienia. Okazało się, że mniej niż połowa ankietowanych (48,9\%, w tym 17 kobiet i 6 mężczyzn) gotowa jest do przyuczenia do zawodu na określonym stanowisku pracy. Tylko 17\% respondentów (6 kobiet i 2 mężczyzn) zadeklarowało chęć przekwalifikowania na specjalistycznym kursie. Niepokojący jest fakt, iż więcej niż jedna trzecia badanych osób z orzeczeniem o stopniu niepełnosprawności (tj. 34,1\%, w tym 9 kobiet i 6 mężczyzn) nie chce podnosić swoich kwalifikacji; nie budzi natomiast zdziwienia to, że nikt nie wyraził chęci podjęcia własnej działalności gospodarczej, co było już przedmiotem analiz w niniejszym punkcie.

Tabela 7. Ocena systemu informowania osób z niepelnosprawnością o możliwościach aktywizacji zawodowej - w opinii badanych

\begin{tabular}{|c|c|c|c|c|c|c|c|}
\hline \multirow{2}{*}{ Lp. } & \multirow{2}{*}{ Odpowiedzi Pleć } & \multicolumn{2}{|c|}{ Kobiety } & \multicolumn{2}{|c|}{ Mężczyźni } & \multicolumn{2}{|c|}{ Razem } \\
\hline & & $\mathrm{L}$ & $\%$ & $\mathrm{~L}$ & $\%$ & $\mathrm{~L}$ & $\%$ \\
\hline 1 & zdecydowanie tak & 0 & 0,0 & 0 & 0,0 & 0 & 0,0 \\
\hline 2 & raczej tak & 0 & 0,0 & 0 & 0,0 & 0 & 0,0 \\
\hline 3 & raczej nie & 23 & 71,9 & 10 & 66,7 & 33 & 70,2 \\
\hline 4 & zdecydowanie nie & 2 & 6,2 & 3 & 20,0 & 5 & 10,6 \\
\hline 5 & trudno powiedzieć & 7 & 21,9 & 2 & 13,3 & 9 & 19,2 \\
\hline & Ogółem & 32 & 100,0 & 15 & 100,0 & 47 & 100,0 \\
\hline
\end{tabular}

Źródło: Opracowanie własne na podstawie badania ankietowego 
Nawiązaniem do poznanych wcześniej opinii badanych była ocena systemu informowania osób z niepełnosprawnością o możliwościach aktywizacji zawodowej. Okazało się, o czym informują wyniki zamieszczone w Tabeli 7, że ocena ankietowanych jest sceptyczna. Znaczna część respondentów - 70,2\% (w tym 23 kobiety i 10 mężczyzn) wskazała odpowiedź: „raczej nie”, zaś co dziesiąty badany $(10,6 \%$, w tym 2 kobiety i 3 mężczyzn) uznał, że „zdecydowanie nie”. Niemal co piąta z ankietowanych osób (19,2\%, w tym 7 kobiet i 2 mężczyzn) nie potrafiła w mniej lub bardziej precyzyjny sposób wyrazić swej opinii na ten temat.

Ostatnim z zagadnień, o które pytano badanych, był wpływ, jaki - ich zdaniem - mogą wywierać programy aktywizujące na zmianę sytuacji osób z orzeczeniem o stopniu niepełnosprawności na rynku pracy, np. poprzez poprawę konkurencyjności. Odpowiedzi zebrano i przedstawiono w Tabeli 8.

Tabela 8. Wpływ programów aktywizacji osób z niepełnosprawnością na zmianę ich sytuacji na rynku pracy - w opinii badanych

\begin{tabular}{|c|c|c|c|c|c|c|c|}
\hline \multirow{2}{*}{ Lp. } & \multirow{2}{*}{ Odpowiedzi Płeć } & \multicolumn{2}{|c|}{ Kobiety } & \multicolumn{2}{|c|}{ Mężczyźni } & \multicolumn{2}{|c|}{ Razem } \\
\hline & & $\mathrm{L}$ & $\%$ & $\mathrm{~L}$ & $\%$ & $\mathrm{~L}$ & $\%$ \\
\hline 1 & zdecydowanie tak & 0 & 0,0 & 0 & 0,0 & 0 & 0,0 \\
\hline 2 & raczej tak & 23 & 71,9 & 5 & 33,3 & 28 & 59,6 \\
\hline 3 & raczej nie & 2 & 6,2 & 7 & 46,7 & 9 & 19,1 \\
\hline 4 & zdecydowanie nie & 0 & 0,0 & 0 & 0,0 & 0 & 0,0 \\
\hline 5 & trudno powiedzieć & 7 & 21,9 & 3 & 20,0 & 10 & 21,3 \\
\hline & Ogółem & 32 & 100,0 & 15 & 100,0 & 47 & 100,0 \\
\hline
\end{tabular}

Źródło: Opracowanie własne na podstawie badania ankietowego

Jak wynika z danych zamieszczonych w Tabeli 8 , ponad połowa badanych (,,raczej tak": 59,6\%, w tym 23 kobiety i 5 mężczyzn) twierdzi, iż programy aktywizacji mają ich zdaniem - pewien wpływ na zmianę sytuacji osób z niepełnosprawnością na rynku pracy. Prawie co piąty z respondentów $-19,1 \%$ (w tym 2 kobiety i 7 mężczyzn) jest zdania, że działania podejmowane w ramach programów aktywizacji osób z dysfunkcjami raczej nie wpływają na zmianę ich sytuacji na rynku pracy. Jednocześnie jedna piąta ankietowanych (21,3\%, w tym 7 kobiet i 3 mężczyzn) nie posiadała wyrobionej opinii na ten temat i wybrała opcję ,trudno powiedzieć”.

\section{Ocena wyników badań}

Głównym celem podjętych badań była próba diagnozy funkcjonowania programów wspierających aktywizację osób z niepełnosprawnością.

Analiza materiału empirycznego zebranego w toku badań własnych, a także osobiste doświadczenia zdobyte $\mathrm{w}$ trakcie kilkuletniej pracy w zakładzie zatrudniającym osoby z orzeczeniem o stopniu niepełnosprawności, umożliwiły wyciągnięcie następujących wniosków:

Osoby z niepetnosprawnościa dość krytycznie oceniaja inicjatywy aktywizujące $i$ instytucje odpowiedzialne za ich realizację: 
- Ponad $3 / 4$ badanych $(76,6 \%)$ uważa, że oferta programów aktywizujących, kierowanych do osób $\mathrm{z}$ orzeczeniem o stopniu niepełnosprawności jest niewystarczająca.

- Ponad 80\% respondentów ocenia sceptycznie system informowania o ofercie i dostępności programów aktywizujących $(70,2 \%$ wskazało odpowiedź: „,raczej nie”, zaś 10,6\% - „zdecydowanie nie”).

- Badani oczekują większej roli i większego zaangażowania ze strony instytucji odpowiedzialnych za wspieranie osób z niepełnosprawnością; głównie dotyczy to instytucji rządowych i władz lokalnych. Większość badanych $(63,8 \%)$ nie brała udziału w programach, które mają służyć aktywizacji zawodowej osób $\mathrm{z}$ orzeczeniem o stopniu niepełnosprawności.

1. Programy aktywizacji nie dość znaczaco wphywają na zatrudnienie osób z niepelnosprawnościa, co znalazło częściowe potwierdzenie w wynikach przeprowadzonych badań, albowiem: 59,6\% ankietowanych twierdzi, iż programy aktywizacji mają pewien wpływ na zmianę sytuacji osób z dysfunkcjami na rynku pracy. Nie ma to jednakże bezpośredniego przełożenia na zatrudnianie ww. osób w związku z ograniczoną liczbą ofert pracy i pewną niechęcią pracodawców do zatrudniania osób z niepełnosprawnością, a także procedurami biurokratycznymi.

2. Programy aktywizacji sluża wyrównywaniu szans osób z orzeczeniem o stopniu niepetnosprawności, lecz, ich sytuacja uzależniona jest bezpośrednio od czynników determinujących rynek pracy, co zostało częściowo zweryfikowane pozytywnie:

- Jak twierdzą wszyscy badani (100\%), sytuacja osób z niepełnosprawnością na rynku pracy jest zdecydowanie gorsza niż osób zdrowych.

- Pracodawcy - zdaniem ankietowanych - niechętnie (83\%) lub bardzo niechętnie (17\%) zatrudniają osoby dotknięte niepełnosprawnością.

- Badani (100\%) są przeświadczeni, że osoby z orzeczeniem o stopniu niepełnosprawności nie są traktowane na rynku pracy na równi z osobami zdrowymi.

Mając zatem na uwadze całość wysuniętych wniosków i refleksji wypływających z przeprowadzonych badań, można stwierdzić, że trafnym było założenie, iż programy aktywizacji osób z niepelnosprawnościa nie posiadają pożądanego wpływu na zmianę sytuacji społeczno-zawodowej tych osób, dlatego też - działając nie tylko w interesie osób $\mathrm{z}$ dysfunkcją - należy dążyć do zmiany istniejącego stanu rzeczy. Tym samym cel badania, jakim było poznanie i zrozumienie funkcjonowania osób z niepełnosprawnością w środowisku pracy, został zrealizowany.

\section{Podsumowanie}

Aktywność zawodowa osób z niepełnosprawnością, jak i wsparcie przeciw wykluczeniu społecznemu powinno być stale promowane, aby grupa tych osób nie pozostawała $\mathrm{w}$ sferze bierności zawodowej. Ponadto trudniej jest osobom z niepełnosprawnością uzyskać dostęp do wysokiej jakości edukacji, usług społecznych, transportu publicznego, działań aktywizujących. Taka sytuacja pociąga 
za sobą olbrzymie koszty społeczne i ekonomiczne, także w postaci niewykorzystanego potencjału tych osób, czy też niższej jakości ich życia.

Sytuacja społeczna osób z orzeczeniem o stopniu niepełnosprawności zdecydowanie częściej wymaga wsparcia i pomocy ze strony innych osób i instytucji. Jednakże, aby działania te przynosiły wymierne korzyści, konieczne jest współdziałanie szeregu podmiotów - począwszy od publicznych, przez społeczne, a skończywszy na prywatnych.

Za szczególny problem można uznać niską aktywność zawodową osób $\mathrm{z}$ niepełnosprawnością oraz wczesną dezaktywizację zawodową. Jakie są przyczyny braku aktywności zawodowej? Jak wynika z przeprowadzonych badań, najczęstszymi przyczynami niechęci podjęcia pracy zawodowej przez osoby niepełnosprawne są: zły stan zdrowia, brak wiary w możliwość znalezienia pracy, negatywne stereotypy dotyczące osób $\mathrm{z}$ orzeczeniem o stopniu niepełnosprawności funkcjonujące w społeczeństwie, co w konsekwencji powoduje strategię przeczekania, brak własnych inicjatyw, pomysłów na poprawę swojego losu. Skutkuje to osłabieniem pozycji osoby $\mathrm{z}$ orzeczeniem o stopniu niepełnosprawności w społeczeństwie i postrzeganie jej przez pryzmat jednej tylko cechy - niepełnosprawności.

Wyniki ogólnopolskich badań wskazują na pewną poprawę sytuacji osób z niepełnosprawnością na rynku pracy w ciągu ostatnich lat. „W 2013 roku aktywnych zawodowo było 17,3\% osób z orzeczeniem o stopniu niepełnosprawności w wieku 15 lat i więcej, a udział osób pracujących wśród osób z dysfunkcjami w wieku 15 lat i więcej w 2013 roku wynosił 14,4\%, stopa bezrobocia 16,9\%" (http://www.niepelnosprawni.gov.pl/niepelnosprawnosc-w-liczbach-/rynek-pracy/). Nie zmienia to jednak faktu, że osoby z niepełnosprawnością wciąż nie wykazują dostatecznej aktywności i w małym stopniu funkcjonują na rynku pracy. Ważną rolę odgrywają tu bariery psychologiczne, środowiskowe i społeczne.

Motywem, który dominuje jako czynnik skłaniający do podejmowania pracy zawodowej przez osoby z dysfunkcjami, jest chęć samodzielnego zarabiania na życie. Osoby z niepełnosprawnością pragną być samodzielne, niezależne od innych. Praca zawodowa może być jedną z najważniejszych dróg do realizacji tego celu.

Analizując sytuację zawodową oraz rynek pracy osób z niepełnosprawnością, należy podkreślić, iż zdecydowana większość respondentów lokuje pracę bardzo wysoko w swoim systemie wartości. Badania dowiodły, że - wbrew powszechnym opiniom - osoby z niepełnosprawnością nie wartościują pracy wyłącznie jako źródła dochodu, ale też postrzegają ją jako ważny składnik oceny własnej osoby. Z drugiej strony, bierność osób z orzeczeniem o stopniu niepełnosprawności skutkuje tym, że niewielu spośród respondentów planuje swoją dalszą karierę zawodową. Jedynie część osób deklaruje podnoszenie swoich kwalifikacji, większość zaś nie zastanawia się nad swoją przyszłością zawodową, zadowalając się stanem obecnym.

Czynnikiem uznawanym za najbardziej powszechny, jeśli chodzi o słabość pomocy świadczonej na rzecz osób z niepełnosprawnością i ich rodzin, jest nie najlepiej rozwinięta i nieczytelna sieć informacyjna oraz trudności w pozyskiwaniu informacji, a także niska jakość i dostępność wiedzy o pomocy przysługującej osobom z niepełnosprawnością. Wniosek, jaki wypływa $\mathrm{z}$ badań, to konieczność poprawienia przepływu informacji i komunikacji na rzecz skorelowanych działań 
podejmowanych wobec poszczególnych kategorii osób niepełnosprawnością oraz wypracowania lepszego modelu informowania tych osób o przysługujących im uprawnieniach.

Należy zwrócić uwagę, że badania zaprezentowane w niniejszym artykule zostały przeprowadzone wśród niepełnosprawnych aktywnych zawodowo, a więc osób, które wykazały już pewną aktywność życiową, podejmując pracę zarobkową. Dowodzą one jednak, iż opinie osób z niepełnosprawnością na temat funkcjonowania instytucji wsparcia nie są pozytywne. Rozmówcy bardzo negatywnie ocenili działania instytucji, np. urzędów pracy, które - w ich opinii - nie odgrywają większej roli w aktywizowaniu niepełnosprawnych do poszukiwania pracy.

Bariery we wspieraniu aktywizacji społecznej osób z niepełnosprawnością, leżące po stronie poszczególnych instytucji, można przełamywać dzięki współpracy z innymi podmiotami, wzajemnie uzupełniającymi i wzmacniającymi swój potencjał. Realizacja usług wysokiej jakości dla osób z niepełnosprawnością wymaga zawiązywania lokalnych partnerstw instytucji, służb i podmiotów oraz osób z różnych sektorów.

Niepokojącą refleksją wypływającą z badań jest fakt, że często osoby z orzeczeniem o stopniu niepełnosprawności uznały proces adaptacji za zakończony i nie są przygotowane na ewentualne zmiany w ich życiu, szczególnie w sferze zawodowej. Wydaje się więc, że działania aktywizujące powinny być kierowane nie tylko do osób poszukujących pracy, ale także do tych już funkcjonujących na rynku, zwłaszcza, że osoby te mają duże poczucie odpowiedzialności za własne życie i zdają sobie sprawę z ich niekorzystnej i niepewnej sytuacji zawodowej. Aktywizacja zawodowa osób z niepełnosprawnością jest zatem ważnym zagadnieniem w polityce społecznej i stanowi istotne wyzwanie dla polityki społecznej w naszym kraju.

\section{Literatura}

1. Barczyński A. (2005), Aktywność zawodowa niepełnosprawnych, „Praca i Rehabilitacja Niepełnosprawnych", nr 10.

2. Barczyński A. (2007), Jakość zarządzania a skuteczność systemu rehabilitacji społecznej i zawodowej osób niepełnosprawnych, Wydawnictwo Akademii Ekonomicznej w Katowicach, Katowice.

3. http://www.europarl.europa.eu/sides/getDoc.do?pubRef=-//EP//TEXT+REPORT+A8-20150222+0+DOC+XML+V0//PL (dostęp: 06.05.2016).

4. http://www.gazetapodatnika.pl/artykuly/stopnie_niepelnosprawnosci-a_2941.htm (dostęp: 06.05.2016).

5. http://www.niepelnosprawni.gov.pl/niepelnosprawnosc-w-liczbach-/rynek-pracy/ (dostęp: 06.05.2016).

6. http://www.niepelnosprawni.gov.pl/p,83,sodir-pfron (dostęp: 06.05.2016).

7. http://www.pfron.org.pl/ (dostęp: 06.05.2016).

8. Pełno spraw dla osób niepełnosprawnych, informacja prasowa, Ministerstwo Rozwoju Regionalnego, 25.05.2011, http://www.efs.gov.pl/ (dostęp: 06.05.2016).

9. Ustawa $\mathrm{z}$ dnia 27 sierpnia $1997 \mathrm{r}$. o rehabilitacji zawodowej i społecznej oraz zatrudnianiu osób niepełnosprawnych (Dz.U. 2011 nr 127 poz. 721, z późn. zm.). 
THE IMPACT OF ACTIVATION PROGRAMMES SUPPORTING PEOPLE WITH DISABILITIES ON CHANGING THEIR SITUATION IN THE LABOUR MARKET

\begin{abstract}
People with disabilities face a number of difficulties and barriers - starting from not adapted school infrastructure and ending with job finding problems. This is the reason that they are especially vulnerable to social exclusion. Implementation of activation programmes helps to eliminate barriers associated with the participation of disabled people in social life. Measures under those programmes support investments in infrastructure adaptation, as well as improving the quality of education and competencies and finally facilitate start in life and career development.
\end{abstract}

Keywords: disability, disabled, activation, labour market 